Please share your stories about how Open Access to this article benefits you.

\title{
Analytical and biological characterization of supercoiled plasmids purified by various chromatographic techniques
}

\author{
by Irina Tumanov et al.
}

2005

This is the published version of the article, made available with the permission of the publisher. The original published version can be found at the link below.

Irina Tumanov et al. (2005). Analytical and Biological Characterization of Supercoiled Plasmids Purified by Various Chromatographic Techniques. DNA and Cell Biology 24(12):819-831.

Published version: http://www.dx.doi.org/10.1089/dna.2005.24.819

Terms of Use: http://www2.ku.edu/ scholar/docs/license.shtml 


\title{
Analytical and Biological Characterization of Supercoiled Plasmids Purified by Various Chromatographic Techniques
}

\author{
IRINA TUMANOVA, ${ }^{1}$ JEAN BOYER, ${ }^{2}$ S. FERNANDO AUSAR,${ }^{3}$ JOSEPH BURZYNSKI, ${ }^{1}$ \\ DANA ROSENCRANCE, ${ }^{1}$ JULIE WHITE, ${ }^{1}$ JASON SCHEIDEL, ${ }^{1}$ ROSE PARKINSON, ${ }^{2}$ \\ HENRY MAGUIRE, ${ }^{2}$ C. RUSSELL MIDDAUGH,${ }^{3}$ DAVID WEINER, ${ }^{2}$ and ANTHONY P. GREEN ${ }^{1}$
}

\begin{abstract}
Supercoiled plasmids are an important component of gene-based delivery vehicles. A number of production methods for clinical applications have been developed, each resulting in very high-quality product with low levels of residual contaminants. There is, however, no consensus on the optimal methods to characterize plasmid quality, and further, to determine if these methods are predictive of either product stability or biological activity. We have produced two plasmids using four production purification methodologies based on PolyFlo $^{\circledR}$ and hydrophobic interaction chromatography (HIC), either alone or in tandem processes. In each case, the product was analyzed using standard molecular biological methods. We also performed a number of biophysical analyses such as dynamic light scattering (DLS), circular dichroism (CD), Fourier transform infrared spectroscopy (FTIR), and differential scanning calorimetry (DSC). Minimal differences were detected among the preparations based on the more standard molecular biological methods. Some small differences were detected, however, using biophysical techniques, particularly FTIR and DSC, which may reflect small variations in plasmid tertiary structure and thermal stability. Stability after heat exposure at $60^{\circ} \mathrm{C}$, exposure to fetal bovine serum and long-term storage at $4^{\circ} \mathrm{C}$ varied between plasmids. One plasmid showed no difference in stability depending on the production process, but the other showed significant differences. Evaluation in vivo in models for gene immunization and gene therapy showed significant differences in the response depending on the method of purification. Preparations using a tandem process of PolyFlo used in two separation modes provided higher biological activity compared to a tandem HIC/PolyFlo process or either resin used alone in a single column process. These data indicate that the process by which supercoiled plasmids are made can influence plasmid stability and biological activity and emphasize the need for more rigorous methods to evaluate supercoiled plasmids as gene-delivery vehicles.
\end{abstract}

\section{INTRODUCTION}

$\mathbf{N}$ ONVIRAL METHODS for the efficient transfer of genes for vaccine and gene therapy applications to specific cell populations continue to focus on supercoiled plasmid DNA as the major therapeutic agent (Kutzler and Weiner, 2004). Applications have been shown for such varied indications as tuberculosis (Derrick et al., 2004), malaria (Smooker et al., 2004; Wang et al., 2005), Hepatitis B (Mancini-Bourgine et al., 2004) and
HIV (Akahata et. al., 2005; Martin et al., 2005; Singh et al., 2005; Smith et al., 2005). With the recent emphasis on vaccines to address biodefense-associated pathogens, considerable work has been applied to organisms such as Marburg, Ebola, Anthrax, and influenza (Riemenschneider et al., 2003; Wang et al., 2004). In most of these experiments, however, only partial protection was achieved. As a result, new strategies to improve biological activity have focused on the plasmid itself or the means of delivery. For example, "Prime-boost" and multiple

\footnotetext{
${ }^{1}$ Puresyn, Inc., Malvern, Pennsylvania.

${ }^{2}$ Department of Pathology and Laboratory Medicine, University of Pennsylvania School of Medicine, Philadelphia, Pennsylvania.

${ }^{3}$ Department of Pharmaceutical Chemistry, University of Kansas, Lawrence, Kansas.
} 
plasmid strategies have been used to recruit both arms of the immune system for DNA vaccines and to recruit more appropriate cofactors for tumor reduction (Sumida et al., 2004; Mascola et al., 2005).

The potential role of the plasmid production process in plasmid stability and biological activity has not been addressed adequately. Many studies have focused on postpurification factors and incorporated the use of lipid, cationic, or polymeric condensing agents as a mechanism to increase transfection efficiency (Gebrekidan et al., 2000; Marshall et al., 2000; Prokop et al., 2002; Mount et al., 2003; Wiethoff et al., 2004). Furthermore, studies on the stability of naked DNA formulations are limited. We have been unable to locate any studies that comprehensively assess effects on biological activity (Evans et al., 2000; Knight and Adami, 2003).

There are several methods for large-scale production of supercoiled plasmid (scDNA) that can meet the rigorous criteria for purity, reproducibility, and scaleability, as well as compatibility with cGMP manufacturing requirements. Many of these processes rely on chromatographic purification of plasmid DNA and include purification methods such as the one developed at Puresyn, Inc. This process, based on the chemically inert, nonporous polymer resin PolyFlo ${ }^{\circledR}$ uses principles of ion-pair reversed phase chromatography to simultaneously purify the scDNA target and eliminate contaminants (Green et al., 1997, 1999). Separation of plasmid isoforms such as open circular (nicked) plasmids from supercoiled forms is based on differences in charge density while reduction of residual contaminants such as RNA, endotoxin, chromosomal DNA, and protein is based on differences in hydrophobicity. Other chromatographic methods use anion-exchange (AEX) or hydrophobic interaction chromatography (HIC) as their primary mode of purification (Diogo et al., 2001a; Eon-Duval and Burke, 2004). We and others, however, have shown anion-exchange chromatography alone cannot produce the quality required for clinical applications; a second technology is required (Eon-Duval and Burke, 2004; Urthaler et al., 2004). As a result, processes that use combinations of AEX and PolyFlo, AEX, and size-exclusion chromatography or AEX and HIC have been developed (Horn et al., 1995; Stadler et al., 2004).

In this paper, we assess the stability and biological activity of two different plasmids produced by four different chromatographic purification methods. The plasmids were analyzed in the absence of complexing agents. In conjunction with these experiments, we applied an extended set of biophysical analytical techniques to determine if plasmid stability can be predicted. The implications of these results are discussed.

\section{MATERIALS AND METHODS}

\section{Plasmids}

The two plasmids used for this study were constructed and provided by Jean Boyer, Ph.D. and David Weiner, Ph.D. (University of Pennsylvania, Philadelphia, PA). The plasmid pCgag02cam is $4877 \mathrm{bp}$ and expresses the HIV-1 clade B gag gene. The transgene has been RNA optimized. High expression was achieved by incorporation of a modified CMV promoter with an optimized enhancer element and the $\mathrm{BGH}$ poly(A) tract.
The plasmid pmuIL-12 is $6598 \mathrm{bp}$ and expresses a covalently linked heterodimeric soluble immune modulator composed of the mouse $35 \mathrm{kDa}$ (p35 or IL-12a) and $40 \mathrm{kDa}$ (p40 or IL-12b) chains. The two IL-12 genes were cloned into a dual promoter/poly(A) plasmid consisting of the human CMV promoter/SV40 poly(A) for IL-12a and the simian CMV promoter/BGH poly(A) for IL-12b. Both plasmids are kanamycin resistant.

Plasmids were transformed into the Escherichia coli host strain DH10 $\beta$ using standard molecular biological techniques. Each plasmid was grown in animal-free Terrific Broth supplemented with glycerol $(30 \mathrm{~g} / \mathrm{l})$ at $37^{\circ} \mathrm{C}$ under fed-batch conditions in a New Brunswick BioFlo 3000 automated fermentor (New Brunswick Scientific, New Brunswick, NJ). Controls for $\mathrm{pH}, \mathrm{DO}$ and agitation were monitored using the BioCommand software (New Brunswick Scientific). After overnight fermentation, the biomass was recovered by centrifugation, washed in TED (25 mM Tris, $10 \mathrm{mM}$ EDTA, and $50 \mathrm{mM}$ Dextrose) and stored at $-20^{\circ} \mathrm{C}$ until use.

\section{Lysis of recovered biomass}

The recovered biomass was lysed using standard Alkali Lysis procedures. In brief, the biomass was resuspended in TED and lysed by the addition of $0.15 \mathrm{M} \mathrm{NaOH} / 1 \%$ SDS. The solution was neutralized by the addition of $\mathrm{KAc} / \mathrm{NH}_{4} \mathrm{Ac}$, the precipitate removed by centrifugation and the solution prepared for chromatography by tangential flow-filtration (TFF) using Pellicon 2 ultrafiltration/diafiltration membranes from Millipore (Bedford, MA). The plasmid was formulated into a buffer appropriate for the subsequent chromatography step.

\section{Chromatography}

Four purification methods were used:

1. (PF) PolyFlo chromatography (PolyFlo, $55 \mu$, Puresyn, Inc., Malvern, PA.) was packed into standard bioprocessing chromatography columns from Millipore (Bedford, MA) and performed as previously described (Green et al., 1997; Green, 1999). In brief, the sample after TFF was formulated into loading buffer ( $2 \mathrm{mM}$ TBAP, $1 \% \mathrm{EtOH}, 0.1 \mathrm{M}$ phosphate buffer, $\mathrm{pH}$ 7.0). After application to PolyFlo, the column was washed with $7.5 \% \mathrm{EtOH}$ and the product eluted in $30 \%$ ethanol.

2. (PF-FT/PF) The tandem process of PolyFlo-Flow-through and PolyFlo requires the crude lysate to be formulated in 9\% EtOH in phosphate buffer without the ion-pairing agent, TBAP. Under these conditions, the plasmid will NOT bind. The unbound fraction was collected, supplemented with TBAP to a final concentration of $2 \mathrm{mM}$ and applied to PolyFlo (as in 1 above).

3. (HIC) Hydrophobic interaction chromatography [Toyopearl Hexyl 650C (Tosoh Biosep, Montgomeryville, PA)] was used in a nonbinding mode. The crude starting material was formulated in TE followed by the addition of solid $\left(\mathrm{NH}_{4}\right)_{2} \mathrm{SO}_{4}$ to a final concentration of $2.1 \mathrm{M}$. After application to the HIC resin, the unbound material was collected and formulated into TE by TFF.

4. (HIC/PF) For material proceeding through the tandem HICPolyFlo the post-HIC material was further formulated into 
PolyFlo loading buffer and the plasmid purified as described in 1 above.

After purification, the plasmid was concentrated by TFF and formulated into TE for testing.

\section{Analytical methods}

Molecular biological techniques. Evaluation of plasmid purity was assessed by agarose gel electrophoresis in the presence of EtBr followed by quantitation by scanning densitometry (AlphaImager, AlphaInnotech). In brief, the percent (\%) DNA homogeneity was determined by application of a $0.2-\mu \mathrm{g}$ sample. This assay has a variability of $\pm 2.0 \%$. Analysis for residual RNA, single-stranded DNA, linear DNA, and chromosomal DNA was also determined by agarose gel electrophoresis, but used a 1.0- $\mu \mathrm{g}$ sample. To improve detection of double-stranded contaminants, gel electrophoresis in the presence of SYBR Green I (Molecular Probes, Eugene, OR) was also performed. The lower limit of detection using this dye is $\sim 1 \mathrm{ng}$. Determination of dimer supercoiled plasmid was based on selected digestion by Exonuclease III (Epicentre, Madison, WI). Analysis for residual endotoxin was performed using the LAL gel clot assay (Associates of Cape Cod, Woods Hole, MA) and for residual protein by the MicroBCA assay (Pierce, Rockford, IL).

\section{Biophysical techniques}

Dynamic light scattering (DLS). Plasmid samples were diluted to $1 \mathrm{mg} / \mathrm{ml}$ in $10 \mathrm{mM}$ HEPES buffer $\mathrm{pH} 7.0$ and filtered twice through $0.45-\mu \mathrm{m}$ filters. To prevent dust contamination, all glassware was exhaustively washed with deionized water. Measurement of the different plasmid sizes was performed with a light-scattering system (Brookhaven Instrument Corp., Holtzille, NY) employing a 50-milliwatt helium-neon laser $(532 \mathrm{~nm})$ incident upon the sample cell immersed in a bath of decalin. The scattered light was monitored at $90^{\circ}$ to the incident beam and analyzed using an autocorrelation function generated by a 522 channel autocorrelator. Data were collected continuously for five 1-min intervals for each sample and averaged. The effective hydrodynamic diameter is calculated from the diffusion coefficient by the Stokes-Einstein equation using the method of cumulants (Choosakonkriang et al., 2003a). Hydrodynamic diameters are expressed as the mean \pm SEM (standard error of the mean) of five determinations.

Circular dichroism $(C D)$. CD spectra were obtained with a Jasco 810 spectropolarimeter (Jasco, Easton, MD) equipped with peltier temperature control and a six-position sample holder. Spectra were acquired in a 1-mm pathlength quartz cuvette at $20^{\circ} \mathrm{C}$. Spectra were measured as the average of three scans at scan rate of $20 \mathrm{~nm} / \mathrm{min}$ with a resolution of $0.2 \mathrm{~nm}$ and a 2-sec response time. The final concentration of all plasmid samples was $50 \mu \mathrm{g} / \mathrm{ml}$. Molar elipticity was calculated in terms of the molar base concentration using an average molecular mass of $324.5 \mathrm{Da}$.

Fourier transform infrared spectroscopy (FTIR). FTIR spectra were obtained with an ABB Bomem FTIR MB series spectrometer (ABB Bomem, Quebec, Canada). For solution studies, samples containing 1 to $1.5 \mathrm{mg}$ of plasmid were mea- sured employing a zinc selenide attenuated total reflectance (ATR) cell (Thermal A.R.K; SpectraTech, Shelton, CT). For samples prepared on polyethylene cards, $50 \mu \mathrm{l}$ of plasmid solution $(1 \mathrm{mg} / \mathrm{ml})$ was deposited onto the center of the polyethylene card and dried overnight under mild vacuum. In this case, transmission mode was used and a background subtraction of dried TE buffer was performed. Spectra were determined from 256 scans at $4 \mathrm{~cm}^{-1}$ resolution. For ATR experiments buffer spectra were subtracted from all sample spectra for solvent correction and the association band of water near $2200 \mathrm{~cm}^{-1}$ was used as a reference. Additional data analysis included baseline correction (1800-800 cm $\mathrm{cm}^{-1}$ ), seven-point Stavisky-Golay smoothing and peak position determination.

Differential scanning calorimetry (DSC). DSC was performed with a Microcal Capillary-DSC (Microcal, Northampton, MA) equipped with an autosampling device. Measurements consisted of a single scan from 20 to $120^{\circ} \mathrm{C}$ at $1{ }^{\circ} \mathrm{C} / \mathrm{min}$ under 3 atmospheres of pressure. All samples were diluted in $10 \mathrm{mM}$ HEPES buffer ( $\mathrm{pH} 7.0$ ) to a final concentration of $1 \mathrm{mg} / \mathrm{ml}$ and degassed under vacuum for at least $10 \mathrm{~min}$. A scan with buffer in both the sample and reference cells was performed to obtain the experimental baseline. The data were converted to molar heat capacity (MHC) using the molecular weight estimated by agarose gel electrophoresis (the band corresponding to the linear topoisomer) and assuming an average MW of 324.5 Da per nucleotide.

\section{Plasmid stability}

Plasmid stability was assessed by measurement of the percent monomer supercoiled plasmid after storage at $4^{\circ} \mathrm{C}$, heatinduced nicking at $60^{\circ} \mathrm{C}$ or exposure to fetal bovine serum (FBS). For the accelerated studies, plasmid was diluted to 1 $\mathrm{mg} / \mathrm{ml}$ in TE and incubated at $60^{\circ} \mathrm{C}$ in a water bath. Samples were removed over the course of $72 \mathrm{~h}$ and assayed for DNA homogeneity by agarose gel electrophoresis. To assess biological stability, plasmid at $0.5 \mathrm{mg} / \mathrm{ml}$ was diluted in $5 \% \mathrm{FBS}$ (JRH, Lenexa, KS) and incubated at $37^{\circ} \mathrm{C}$. Samples were removed over the course of $8 \mathrm{~h}$ and assayed for DNA homogeneity by agarose gel electrophoresis.

\section{Assessment of biological activity}

Immunization study. Mice were immunized with 50 and $150 \mu \mathrm{g}$ of plasmid from each of the four processes (Table 1) at days 0,14 , and 28. Formulation buffer containing no plasmid was used as a control ("mock"). Samples were taken 1 week after each immunization for cellular immunity analysis and the final immunization humoral immunity. CD8 responses were evaluated using the Cytokine ELISPOT-CD8 ELISA Assay using IFN- $\gamma$ as a surrogate marker and performed according to the manufacturer's instructions (R\&D Systems, Minneapolis, MN). CD8 effector cells secrete IFN- $\gamma$ following activation with antigen specific peptides. In this case, MHC Class I gag epitopes were utilized. Results are presented as the number of IFN $\gamma^{+}$cells $/ 10^{5}$ spleen cells. Antibody responses to the p24 antigen were determined by ELISA. In brief, antigencoated plates were incubated with mouse antisera and concentrations determined using HRP-conjugated goat antimouse IgG (Sigma, St. Louis, MO). After addition of $3^{\prime} 3^{\prime} 5^{\prime} 5^{\prime} \mathrm{TMB}$ 


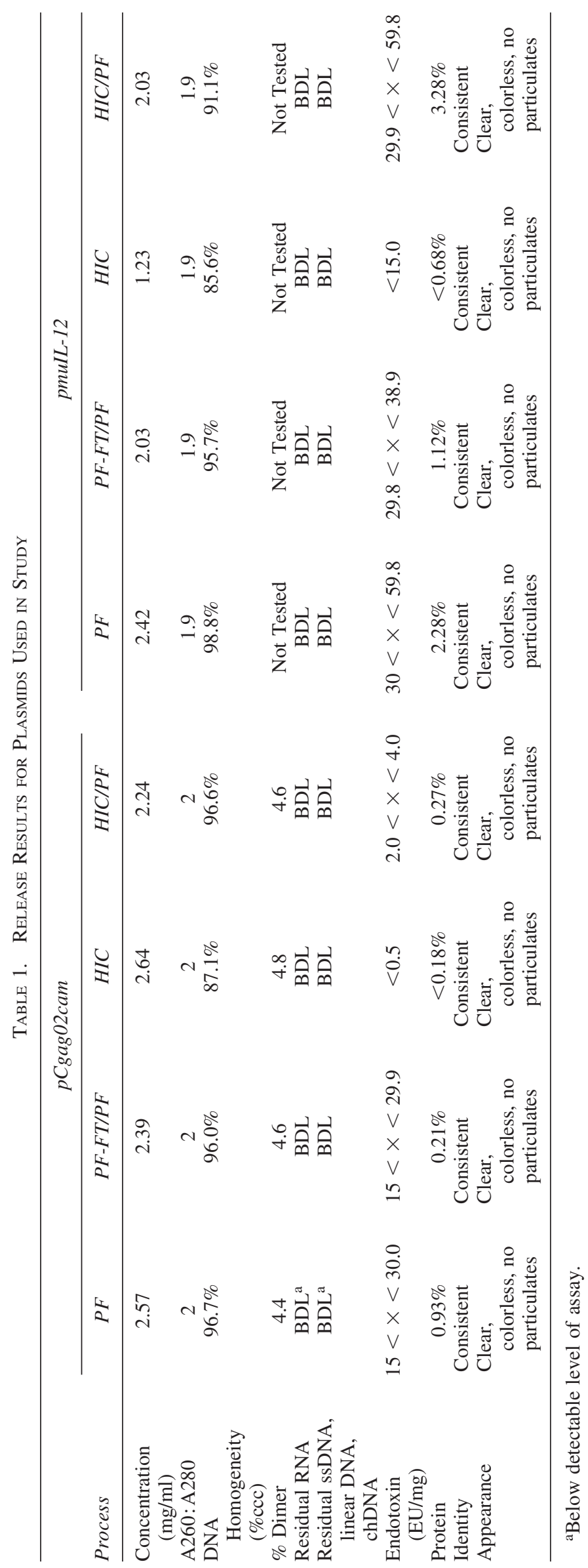


(Sigma), the plates were read on a Dynatech MR50000 plate reader at $450_{\mathrm{nm}}$.

Gene therapy study. A second experiment used the plasmid pmuIL-12 in a tumor reduction model of gene therapy. In brief, CT-26 tumor cells were injected intradermally into Balb/c mice. When the tumors attained an average diameter of 4-8 $\mathrm{mm}$, they were injected intratumorally with $40 \mu \mathrm{l}$ of pmuIL-12 that day and 3 days later. Comparison was made between the growth rates of the tumors using different purification processes and plasmid at different DNA homogeneity. Plasmid purified by HIC alone was not used in this study based on the results of the immunization study. Group 1 consisted of plasmids as they were released ( $>90 \%$ DNA homogeneity), Group 2 consisted of plasmids subjected to heat-induced nicking to produce plasmid at DNA homogeneity target level of 75-80\%. Group 3 consisted of plasmids subjected to heat-induced nicking to produce plasmid at a DNA homogeneity target level of 50-60\%.

\section{RESULTS}

\section{Purification}

Plasmids pCgag02cam and pmuIL-12 were purified by four different chromatographic processes (Table 1). Both single-column and tandem-column methods were used. For the tandemcolumn processes, the first column, either HIC or PolyFlo, buffer conditions were used such that the plasmid did not bind. For HIC chromatography, this was accomplished by adjustment of the concentration of ammonium sulfate. For PolyFlo-FlowThrough (PF-FT) chromatography, the sample is applied to the resin in the absence of the ion-pairing agent, TBAP. Under these conditions, the resin is used to adsorb denatured and linear plasmid, chromosomal DNA, and endotoxin. In both cases, the flow-through fraction was collected and formulated for application to PolyFlo by TFF.

\section{Analytical results}

Molecular biological characterization. The results of the analysis of the two plasmids purified by the various methods by molecular biological techniques are shown in Table 1. No significant differences among the plasmid preparations after purification are detected in the presence of EtBr (Table 1) or SYBR Green I (Fig. 1) except for the DNA homogeneity of the HICalone preparation. No contaminating RNA or chromosomal DNA is detected using either stain. SYBR Green I exhibits an increase in sensitivity of up to 25-fold when compared to EtBr with a lower limit of detection of $\sim 1 \mathrm{ng}$ dsDNA. As a result, the level of contaminating chromosomal DNA is $<0.1 \%$ ( $1 \mathrm{ng} / 1$ $\mu \mathrm{g}$ sample). Furthermore, SYBR Green I staining is able to resolve additional bands, including denatured plasmid ("trefoil") in heat-stressed pmuIL-12 indicated by the line in Figure 1B.

Biophysical characterization. Each of the plasmid preparations was also analyzed by several biophysical techniques, including dynamic light scattering (DLS), circular dichroism (CD), Fourier-transform Infrared spectroscopy (FTIR), and differential scanning calorimetry (DSC). These techniques have been introduced recently to evaluate supercoiled plasmid stability and quality (Middaugh et al., 1998).

Dynamic light scattering (DLS). To investigate plasmid size and homogeneity, the mean effective hydrodynamic diameters and polydispersity indexes were measured by DLS. Overall, the data show no significant differences for either plasmid purified by any of the processes tested (Table 2). In general, the sizes of the resulting plasmid particles were between 85 and $95 \mathrm{~nm}$ and they all display significant heterogeneity (polydispersity $>0.2$ ),
A

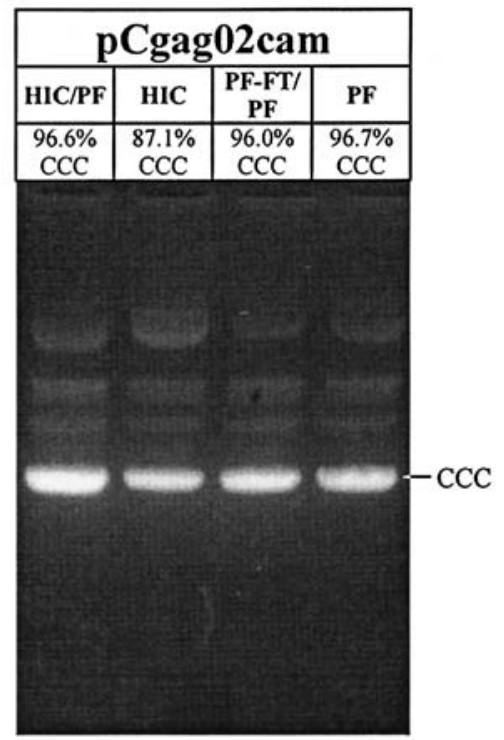

B

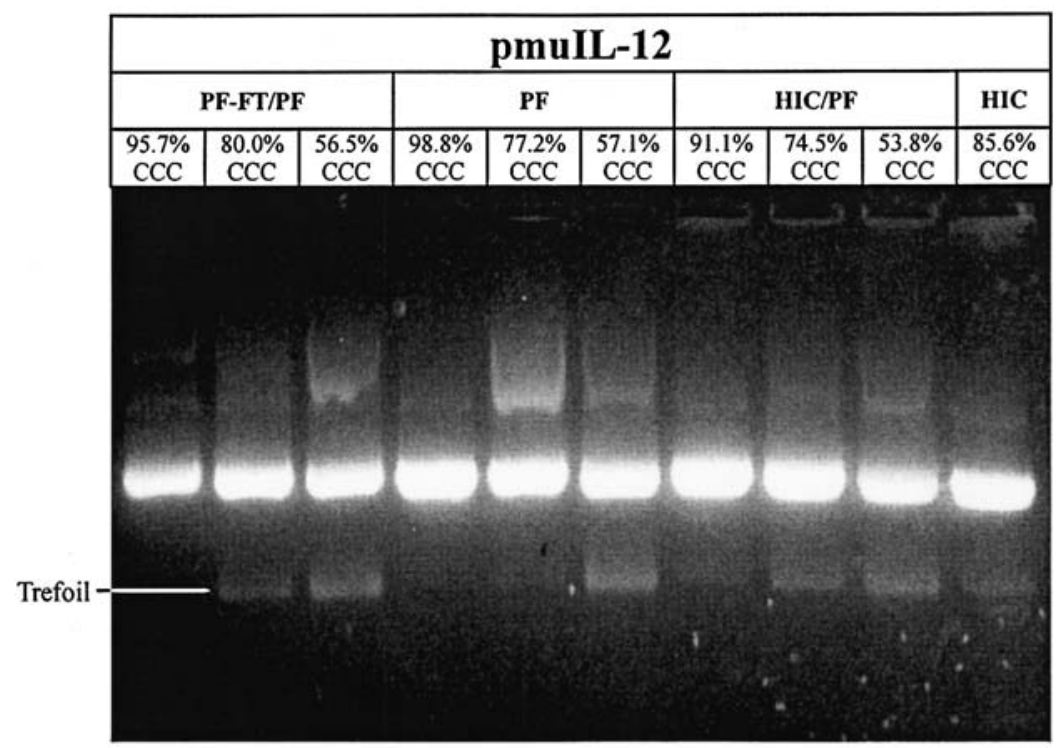

FIG. 1. Agarose gel electrophoresis of plasmids pCgag02cam (A) and pmuIL12 (B). The process used and the \%DNA homogeneity is provided above each lane. 
Table 2. Effective Diameter and Polydispersity Index of Plasmid Samples as Determined by Dynamic Light Scattering

\begin{tabular}{|c|c|c|c|c|c|c|}
\hline \multirow[b]{2}{*}{ Process } & \multicolumn{3}{|c|}{ pCgag02cam } & \multicolumn{3}{|c|}{ pmuIL-12 } \\
\hline & $\begin{array}{c}D N A \\
\text { homogeneity }\end{array}$ & $\begin{array}{l}\text { Diameter } \\
(\mathrm{nm})\end{array}$ & $\begin{array}{l}\text { Polydispersity } \\
\text { index }\end{array}$ & $\begin{array}{c}D N A \\
\text { homogeneity }\end{array}$ & $\begin{array}{l}\text { Diameter } \\
(\mathrm{nm})\end{array}$ & $\begin{array}{l}\text { Polydispersity } \\
\text { index }\end{array}$ \\
\hline PolyFlo & $96.7 \%$ & $85.9 \pm 0.5$ & $0.238 \pm 0.011$ & $98.8 \%$ & $85.6 \pm 2.2$ & $0.287 \pm 0.024$ \\
\hline PF-FT/PF & $96.0 \%$ & $90.6 \pm 1.1$ & $0.278 \pm 0.002$ & $95.7 \%$ & $84.0 \pm 2.7$ & $0.295 \pm 0.015$ \\
\hline $\mathrm{HIC}$ & $87.1 \%$ & $96.4 \pm 2.4$ & $0.250 \pm 0.009$ & $85.6 \%$ & $87.7 \pm 1.1$ & $0.291 \pm 0.003$ \\
\hline HIC-PF & $96.6 \%$ & $92.0 \pm 1.9$ & $0.274 \pm 0.009$ & $91.1 \%$ & $94.3 \pm 4.0$ & $0.331 \pm 0.036$ \\
\hline
\end{tabular}

presumably due to the presence of small amounts of multimeric isoforms of supercoiled plasmid and nonsupercoiled species (linear and open circular topoisomers). The degree of polydispersity, however, was similar for all preparations. Particle diameter and polydispersity did not correlate with DNA homogeneity; thus, plasmid purified by HIC alone, resulting in the lowest \%DNA homogeneity among the preparations, did not result in the largest particle diameter or the greatest polydispersity.

Circular dichroism (CD) and Fourier transform infrared spectroscopy (FTIR). Initially, CD spectra of each plasmid were obtained to see if any alteration in the structure of scDNA was present among the samples. All plasmid preparations showed identical DNA spectral features indicative of B-form DNA, which are characterized by a positive band near $275 \mathrm{~nm}$, a negative trough around $245 \mathrm{~nm}$ and a crossover point near $258 \mathrm{~nm}$ (not illustrated). To further investigate potential structural alteration in the DNA, the higher resolution technique of infrared spectroscopy was employed. The FTIR spectrum of each plasmid in solution is displayed in Figure 2. Vibrational features indicative of B-form DNA include the guanine/thymidine $(\mathrm{G} / \mathrm{T})$ carbonyl stretching band at $1716 \mathrm{~cm}^{-1}$ (representative of interstrand base pairing), an asymmetric phosphate stretching vibration at around $1224 \mathrm{~cm}^{-1}$, and a sugar-phosphate stretching vibration at around $970 \mathrm{~cm}^{-1}$. Overall, most of these bands are present in all of the plasmid spectra in solution (Fig. 2) and were found to have similar positions suggesting that DNA is mantained in the B-form regardless of the purification process employed here. No differences were detected by FTIR for plasmid pCgag02cam after purification (Fig. 2A). There are, however, some small differences for the plasmid pmuIL-12 in the spectral region located between $1300-1200 \mathrm{~cm}^{-1}$ (Fig. 2B). When pmuIL-12 was purified by either PF-FT/PF or PF alone, a band at $\sim 1260 \mathrm{~cm}^{-1}$ was detected. When the same plasmid was purified by $\mathrm{HIC} / \mathrm{PF}$ or HIC alone, however, the peak at $\sim 1260 \mathrm{~cm}^{-1}$, was less intense or even undetectable (Fig. 2B). The origin of these bands is currently obscure but the differences seen may reflect subtle structural differences. When the same plasmid was studied in the dry state adsorbed to polyethylene cards, significant alteration in relative band intensities and bandwidth were observed when compared to the samples in solution (Fig. 3). Similar results have been previously reported and appear to be related to the dehydration of DNA after drying on the solid support. In this case, the DNA may adopt a mixed $\mathrm{A}$ and $\mathrm{C}$ conformation (Choosakonkriang et al., 2003b). Comparing the spectra in the dry state of plasmid obtained by the different purification processes, no clear differences were observed among the preparations (Fig. 3). Altogether, the re-

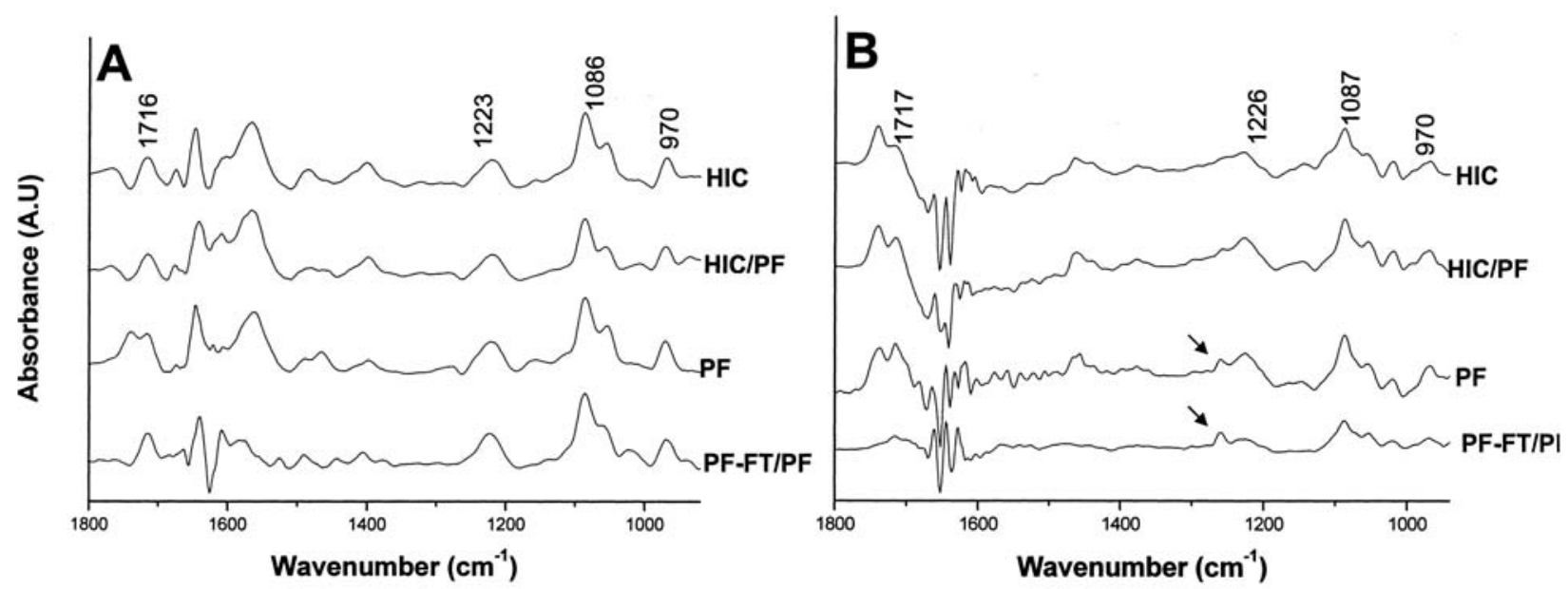

FIG. 2. FTIR spectra in solution of plasmids pCgag02cam $(1.5 \mathrm{mg} / \mathrm{ml})(\mathbf{A})$ and pmuIL-12 (1 mg/ml) (B). The purification processes are indicated. (PF:PolyFlo; PF-FT/PF: PolyFlo-Flow-through and PolyFlo; HIC/PF: hydrophobic interaction chromatography and PolyFlo; HIC: hydrophobic interaction chromatography.) The arrows indicate bands discussed in the text. 


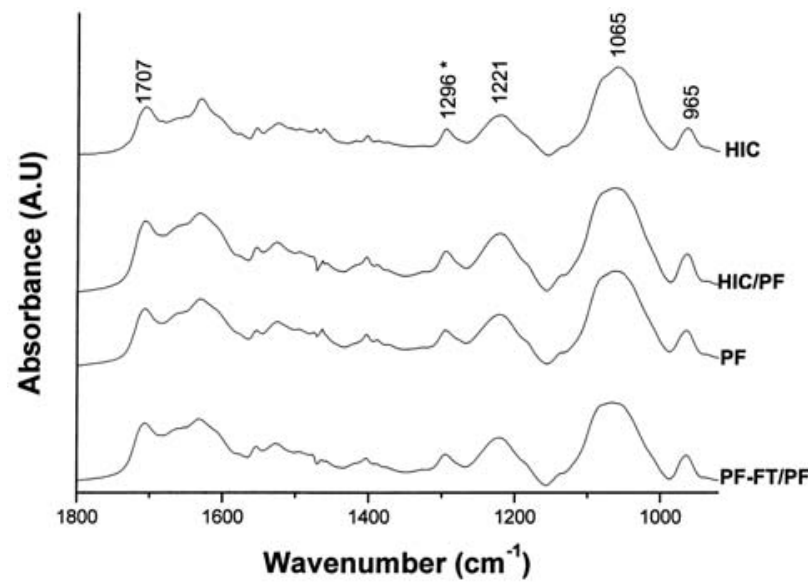

FIG. 3. FTIR spectra of plasmid pmuIL-12 $(1 \mathrm{mg} / \mathrm{ml})$ dried on polyethylene films. The purification processes are indicated. (PF:PolyFlo; PF-FT/PF: PolyFlo-Flow-through and PolyFlo; HIC/PF: hydrophobic interaction chromatography and PolyFlo; HIC: hydrophobic interaction chromatography.) The band label with the asterisk indicates incompletely subtracted bands from the buffer.

sults suggest that if any alterations in the secondary structure of DNA are induced by the purification process they only are evident when the molecules are in solution. Many more plasmids purified by these methods would need to be examined to determine the generality of these observations.
Differential scanning calorimetry (DSC). DSC is a sensitive method for determining plasmid thermal stability (Lobo et al., 2002). Thermograms of all of the plasmids preparations are shown in Figure 4. Overall, plasmids undergo two melting transitions within the scan range: scDNA is detected as a broad transition around $85-95^{\circ} \mathrm{C}$, whereas the linear and open circular species (L/OC) produce a series of transitions between 50 and $70^{\circ} \mathrm{C}$ (Fig. 4). The plasmid pCgag02cam seems to be comparatively more stable than pmuIL-12, since the thermograms exhibit a higher scDNA melting transition (around $10^{\circ} \mathrm{C}$ greater) and a lower contribution from OC/L topoisomers. As seen with the FTIR data, no difference was detected for plasmid pCgag02cam whatever the purification method (Fig. 4A). A difference was detected, however, for plasmid pmuIL-12 when purified by the PF-FT/PF process compared to the other three methods (Fig. 4B). The presence of an additional broad transition at $\sim 105^{\circ} \mathrm{C}$ not seen in any of the other preparations suggests the existence of a more thermal stable species (Fig. 4B). If the DSC profile provides a true indicator of stability, then the stability of the plasmid produced by the PF-FT/PF process should be different than that of the other preparations. This, in fact, is confirmed by the accelerated stability studies (see below, Figs. 5 and 6).

\section{Stability studies}

Plasmid DNA stability was monitored after storage at $4^{\circ} \mathrm{C}$, by accelerated stability studies after heat exposure at $60^{\circ} \mathrm{C}$ or incubation in the presence of 5\% FBS. Measurement of DNA
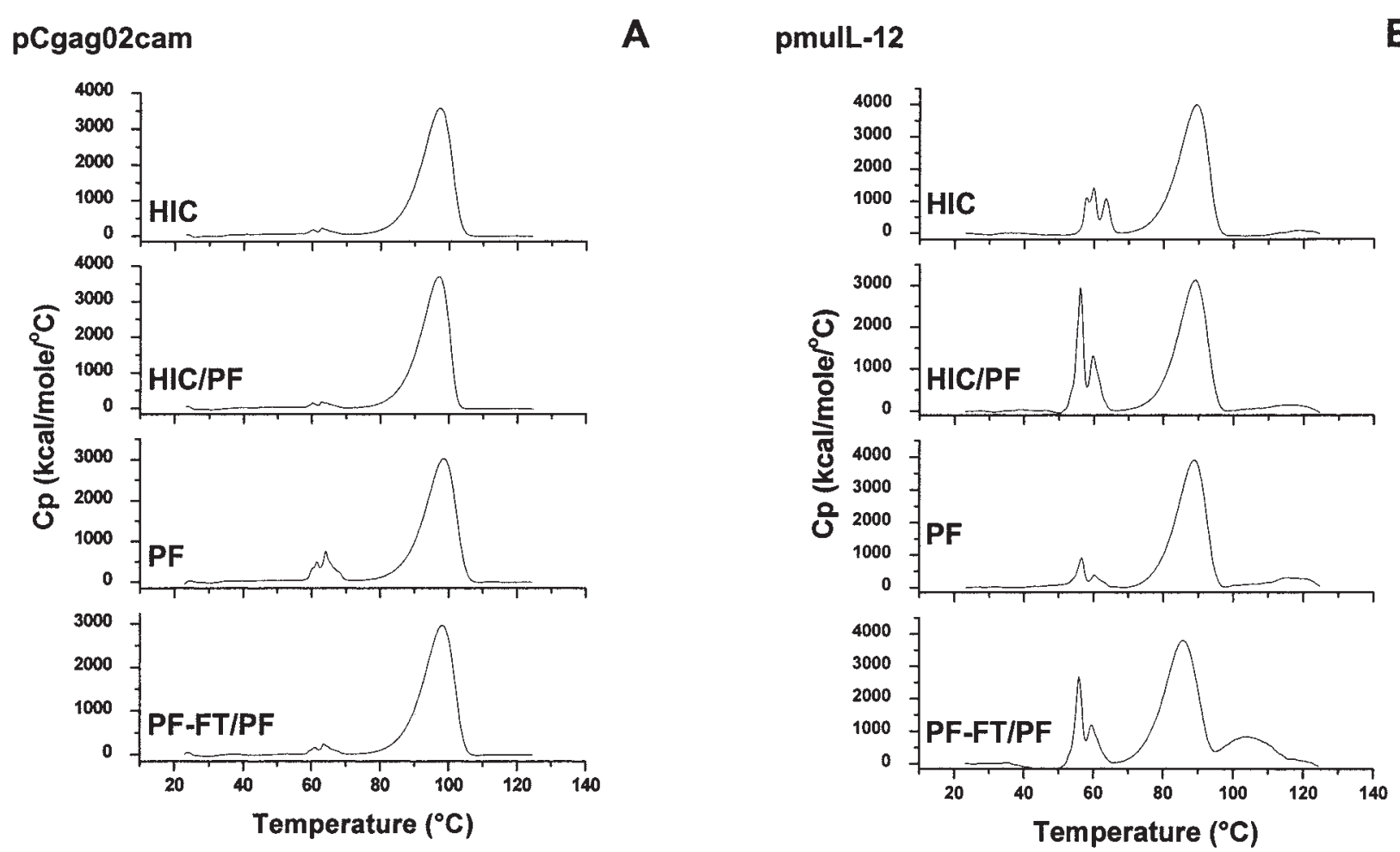

FIG. 4. DSC analysis of plasmids pCgag02cam (A) and pmuIL-12 (B). The purification processes are indicated. (PF:PolyFlo; PF-FT/PF: PolyFlo-Flow-through and PolyFlo; HIC/PF: hydrophobic interaction chromatography and PolyFlo; HIC: hydrophobic interaction chromatography.) 
A

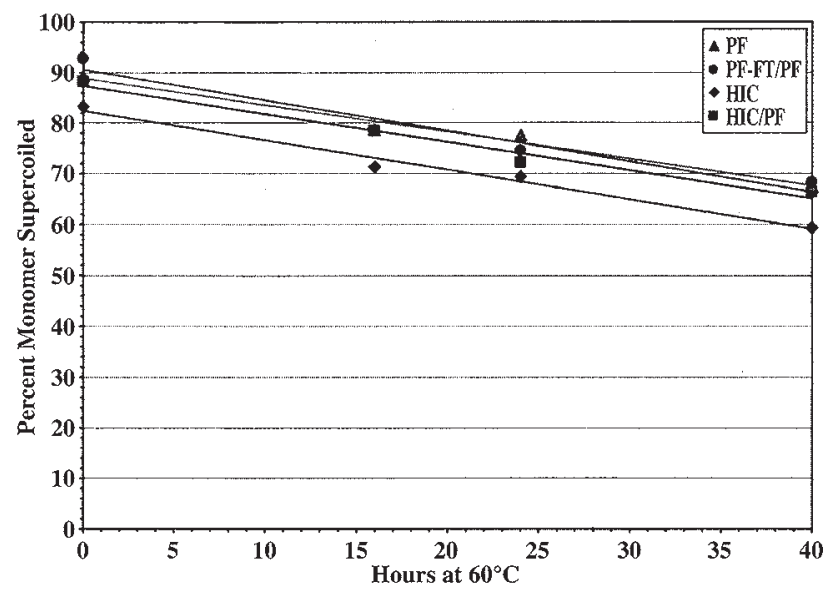

B

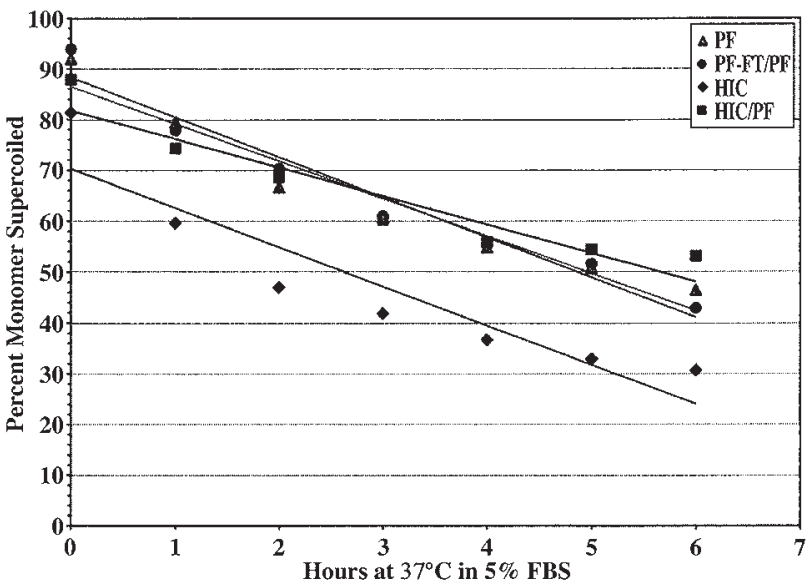

FIG. 5. Stability of plasmid pCgag02cam at $60^{\circ} \mathrm{C}(\mathbf{A})$ and incubation with $5 \%$ FBS (B) obtained by different chromatographic purification processes. (PF:PolyFlo; PF-FT/PF: PolyFlo-Flow-through and PolyFlo; HIC/PF: hydrophobic interaction chromatography and PolyFlo; HIC: hydrophobic interaction chromatography.)

homogeneity was determined by agarose gel electrophoresis. In general, the rates of reduction appear identical between the two methods of stress induction as well as stability at $4^{\circ} \mathrm{C}$. The stability of the plasmid pCgag02cam at $4^{\circ} \mathrm{C}$ was identical, $<4 \%$ after 14 months, regardless of the purification process. These results are consistent with the data shown in Figure 5-no difference is seen in four different preparations of plasmid $\mathrm{pC}$ gag02cam after stress at $60^{\circ} \mathrm{C}$ or FBS exposure. In contrast, significant differences are seen in the stability of plasmid pmuIL-12 among the three purification processes tested (Fig. 6 ). The HIC process was not included in the temperature analysis due to a DNA homogeneity level of $<90 \%$ (Table 1 ). The tandem PF-FT/PF process produced plasmid with an initial DNA homogeneity of $95.7 \%$, and resulted in a highly stable preparation. An accelerated stability study by heating for as long as $65 \mathrm{~h}$ only reduced the percentage of supercoiling by
$30 \%$ (Fig. 6A) and a reduction of less than $10 \%$ after exposure to $5 \%$ FBS for $7 \mathrm{~h}$ (Fig. 6B). Long-term stability at $4^{\circ} \mathrm{C}$ was excellent, with a reduction of DNA homogeneity of only $2 \%$ after 8 months (95.7 to $93.6 \%$ ). In contrast, a $30 \%$ reduction in the supercoiled species was seen for the $\mathrm{HIC} / \mathrm{PF}$ and $\mathrm{PF}$ processes after heating for only $12 \mathrm{~h}$ and a $40 \%$ reduction after $7 \mathrm{~h}$ exposure to FBS. These data correlate with the higher rate of reduction in the supercoiled species after 8 months at $4^{\circ} \mathrm{C}$ with the $\mathrm{HIC} / \mathrm{PF}$ process $(14 \%)$ and the PF process $(21 \%)$.

\section{Assessment of biological activity}

We further evaluated the two plasmids by two different in vivo studies to determine if the process by which the plasmids were produced affected biological activity. The first experiment used the plasmid pCgag02cam in a DNA immunization proto-
A

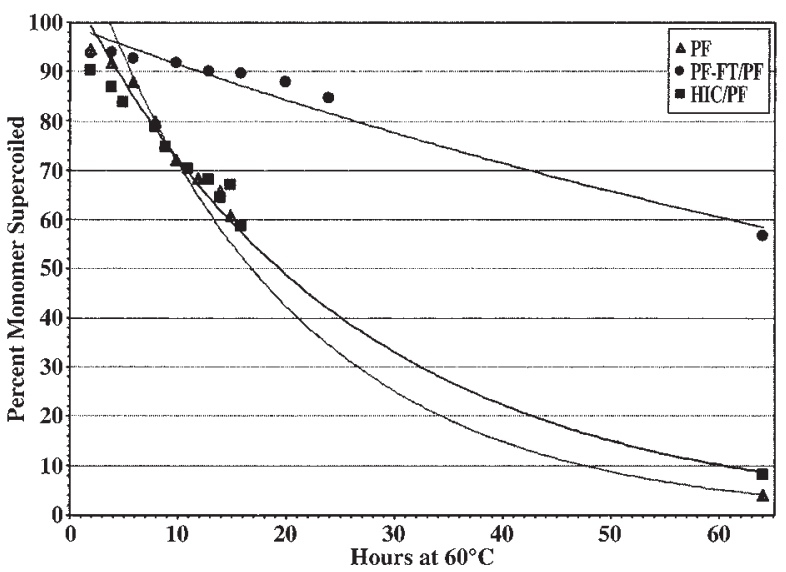

B

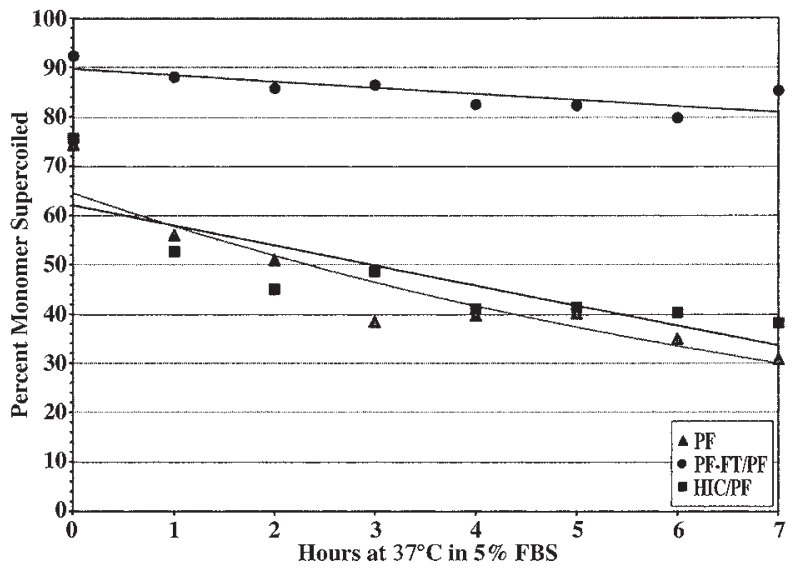

FIG. 6. Stability of plasmid pmuIL- 12 at $60^{\circ} \mathrm{C}(\mathbf{A})$ and incubation with $5 \% \mathrm{FBS}(\mathbf{B})$ obtained by different chromatographic purification processes. (PF:PolyFlo; PF-FT/PF: PolyFlo-Flow-through and PolyFlo; HIC/PF: hydrophobic interaction chromatography and PolyFlo; HIC: hydrophobic interaction chromatography.) 


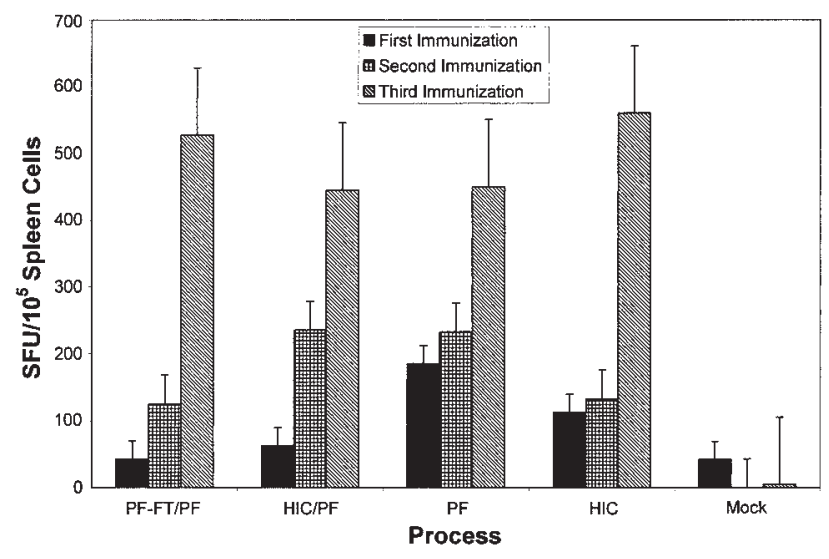

FIG. 7. CD8 responses after three immunization with $150 \mu \mathrm{g}$ pCgag02cam (SFU/10 5 spleen cells \pm SEM).

col followed by analysis for cellular immunity (CD8 ${ }^{+}$Elispot) and humoral immunity (antibody titers). While there was no detectable difference in either response at the highest dose, 150 $\mu \mathrm{g}$ (Figs. 7 and 8), there was a significant difference at the lowest dose $(50 \mu \mathrm{g})$. The PF-FT/PF process produced the highest cellular response (Fig. 9) and the highest antibody response (Fig. 10). These results were not expected, since there are no detectable differences among the preparations based on the standard molecular (Table 1) and biophysical analytical analyses for pCgag02cam (Figs. 2A and 4A) or pmuIL-12 in its dried state (Fig. 3).

The second study used intratumor injection of plasmid pmuIL-12 to reduce CT-26 induced tumors. Again, the plasmid produced by the HIC process was excluded due to the low DNA homogeneity. As can be seen in Table 3, when plasmid was injected with \%DNA homogeneity $>90 \%$ (group 1), the two tan- dem processes resulted in a slower rate of tumor growth at days 17 and 21, compared to PolyFlo alone. By day 21 post-injection, the growth rate of the tumors accelerated, although the tandem process material appeared to keep tumor growth in check. The rate of tumor growth in group 1 did not correlate strictly with DNA homogeneity-the most efficacious response was seen with the tandem processes [PF-FT/PF (95.7\%) and HIC/PF (91.1\%)] compared to PolyFlo alone (98.8\% DNA homogeneity).

When plasmids were subjected to heat-induced nicking to achieve a DNA homogeneity target level of 75-80\% (group 2), there was no difference in activity between the two tandem processes at day 17 and both were more biologically active compared to the single PolyFlo process. By Day 21, only the PF-FT/PF process material retained its biological activity. Surprisingly, there was minimal difference in the activity of the plasmid produced by the tandem PF-FT/PF process at both 95.7 and $80 \%$ homogeneity. Whether these results can be explained by the differences in DNA homogeneity ( 80 versus $74.5 \%$ and $77 \%$ ) or by the increased stability of the plasmid produced by the PF-FT/PF process (Fig. 6) cannot be determined from the current data. However, the day 21 data with the group 2 plasmids clearly favor the increase in stability as a factor in biological activity. Group 3 consisted of plasmids subjected to heat-induced nicking to produce plasmid at a DNA homogeneity target level of 50-60\% and showed no effect-there was no reduction of tumor compared to the control suggesting the biological activity of plasmids below $60 \%$ purity may be compromised (data not shown).

\section{DISCUSSION}

The present investigation focused on the effects of supercoiled plasmid production on stability and biological activity.

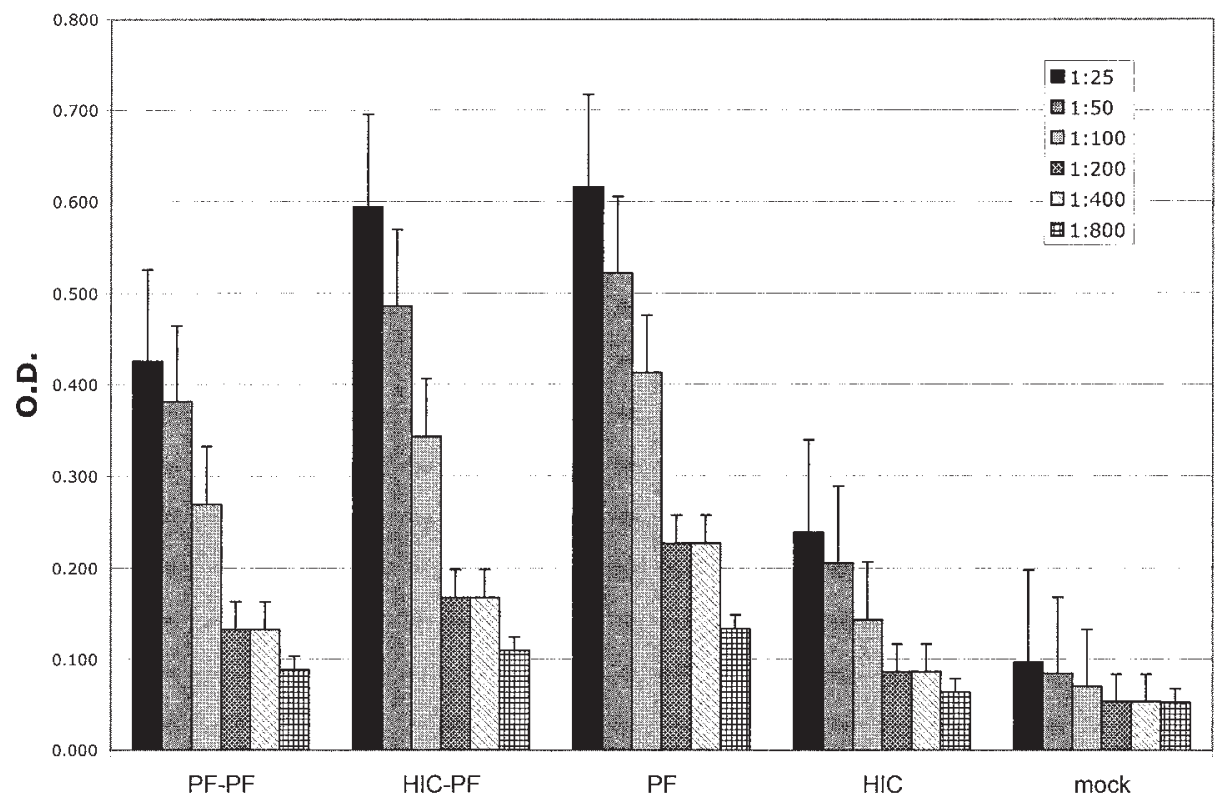

FIG. 8. ELISA titers after three immunizations with $150 \mu \mathrm{g}$ pCgag02cam $\left(\mathrm{OD}_{450 \mathrm{~nm}} \pm \mathrm{SEM}\right)$. 


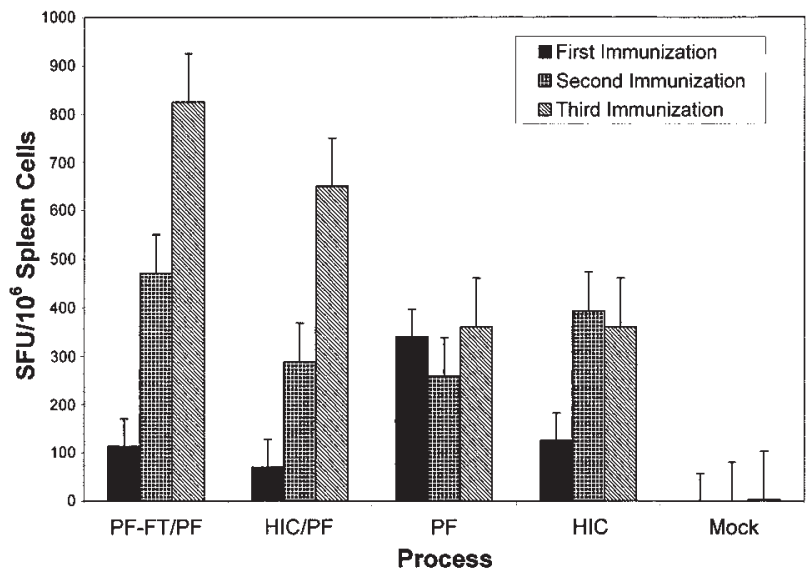

FIG. 9. CD8 responses after three immunization with $50 \mu \mathrm{g}$ pCgag02cam (SFU/10 5 spleen cells \pm SEM).

Two plasmids were purified using four different methods-two single-column procedures and two tandem column procedures. The plasmid product was not formulated further into complexes with cations, lipids, or polymers. The product of each procedure was subjected to analysis by standard molecular biological methods and a number of biophysical methods (Lobo et al., 2002, 2003; Braun et al., 2003; Choosakoonkriang et al., 2003a) and assessed for stability using heat-induced stress. The product of each procedure was subsequently used in vivo to assess the effects of the process on biological activity. Plasmid pmuIL12 was subjected to heat-induced nicking to achieve a specific set point of 75-80\% and 55-60\% DNA homogeneity (Fig. 1). Samples at these lower set points were also analyzed using the biophysical techniques.

No detectable differences were seen in either plasmid pro- duced by different purification processes using standard molecular biological analytical techniques (Fig. 1, Table 1). Yet significant differences in biological activity were seen, particularly at low doses (Figs. 9 and 10 and Table 3). The results show a tandem purification process appears to be superior biologically to a single process. This confirms our previous results showing the process by which recombinant adenovirus and recombinant adeno-associated virus is made can have a significant impact on stability and biological activity (Green et al., 2002; Rexroad et al., 2003). The degree of plasmid supercoiling appears to compromise biological activity EXCEPT in the case of the tandem PF-FT/PF process (Table 3). Plasmids with supercoiling in the 50-60\% range showed no biological activity compared to controls (data not shown). This may reflect rapid degradation of the plasmid by nucleases. It further suggests there is a minimum threshold of DNA homogeneity for biological activity.

Assessment of plasmid stability by heat-induced nicking at $60^{\circ} \mathrm{C}$, exposure to $5 \% \mathrm{FBS}$ or "real-time" stability at $4^{\circ} \mathrm{C}$ showed a significant difference between the two plasmids (Figs. 5 and 6). The stability of plasmid pCgag02cam was not affected by the method of purification. In contrast, the stability of plasmid pmuIL-12 manifested increased stability when purified by the tandem PF-FT/PF method, while no difference was seen between the single PF and tandem HIC/PF method. Interestingly, the increase in stability of the PF-FT/PF process was seen using all three methods. These results cannot be explained by the amount of supercoiled plasmid present or the amount of trefoil (denatured) plasmid (Fig. 1). This suggests multiple factors can contribute to plasmid stability, although there is a slight but inconsistent correlation with residual protein levels. It is in this context the results of the biophysical characterization of the two plasmids provide a basis for their inclusion in the analysis of supercoiled plasmids. CD spectra were identical in both plasmids produced by the four purification methods. However,

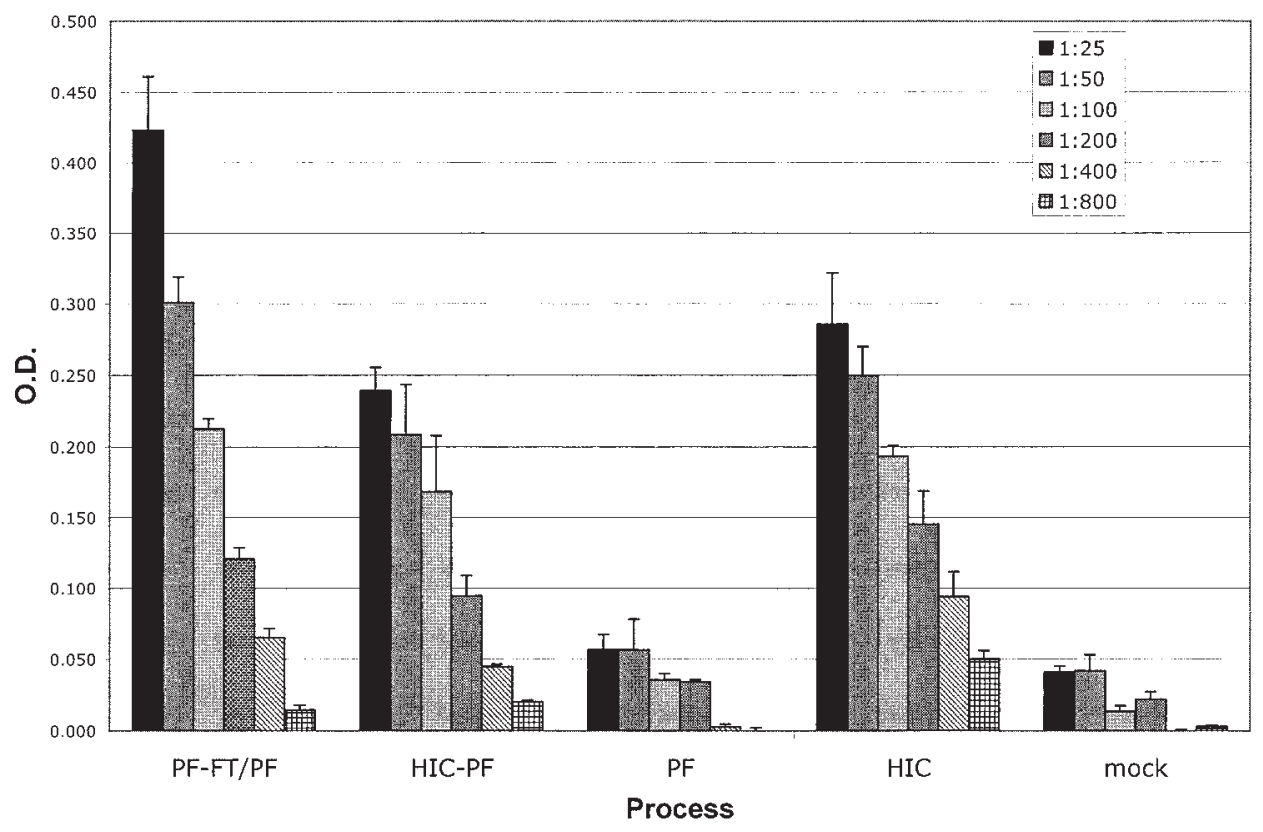

FIG. 10. ELISA titers after three immunizations with $50 \mu \mathrm{g}$ pCgag02cam $\left(\mathrm{OD}_{450 \mathrm{~nm}} \pm \mathrm{SEM}\right)$. 
Table 3. Tumor Reduction by Plasmid pmull-12 at Days 17 and 21 Postinjection by Different Processes at Different LeVels of DNA Homogeneity

\begin{tabular}{llcrr}
\hline & & & \multicolumn{2}{c}{ \% Tumor reduction } \\
\cline { 3 - 5 } & Process & DNA homogeneity & Day 17 & Day 21 \\
\hline Group 1 & PF-FT/PF & $95.7 \%$ & $80.4 \%$ & $53.2 \%$ \\
& HIC/PF & $91.1 \%$ & $82.7 \%$ & $54.2 \%$ \\
Group 2 & PF & $98.8 \%$ & $0.4 \%$ & $23.1 \%$ \\
& PIC/PF & $80.0 \%$ & $74.8 \%$ & $41.9 \%$ \\
& PF & $74.5 \%$ & $66.9 \%$ & $0.0 \%$ \\
& & $77.2 \%$ & $34.8 \%$ & $6.3 \%$ \\
\hline
\end{tabular}

while no differences were detected in plasmid pCgag02cam by DLS (Table 3), FTIR (Fig. 2A), or DSC (Fig. 4A) among the four different preparations, a significant difference was seen in plasmid pmuIL-12 using FTIR (Fig. 2B) and DSC (Fig. 4B). The fact that the differences are seen only in the plasmid pmuIL12 strongly suggests that the structural and stability alterations could be plasmid-specific. Significant differences also emerged after stress or long-term storage at $4^{\circ} \mathrm{C}$. Whether these differences are a direct indicator of stability, a noninformative byproduct of the samples or simply a coincidence requires further study. One possibility is that secondary solutes used during some of the purification steps (i.e., ammonium sulfate and ethanol) have some effect on the structure and stability of the plasmid, but this requires further investigation.

The processes tested in these experiments exploit differences in hydrophobicity and charge density among different nucleic acid species to achieve separation. Hydrophobic interaction chromatography (HIC) has become an important new separation modality for the production of supercoiled plasmid (Diogo et al., 2000, 2001a, 2001b). In particular, HIC can remove contaminating RNA, denatured plasmid, host chromosomal DNA, and endotoxin by exploiting the increase in hydrophobicity of single-stranded nucleic acid species and endotoxin. Separation occurs by the application of a salt gradient. PolyFlo uses principles of ion-paired reversed-phase chromatography for separation of nucleic acid species based on the combination of differences in hydrophobicity and charge density (Green et al., 1997; Green, 1999). Separation occurs by the application of an organic solvent gradient. The addition of the ion-pairing agent TBAP to a crude lysate creates the ion-pair bridge between the phosphate backbone and the hydrophobic PolyFlo matrix. The strength of that binding is based on the number of phosphates (size) and charge density. This permits simultaneous separation of RNA and chromosomal DNA from plasmid, as well as nonsupercoiled isoforms, such as open circular plasmid from supercoiled plasmid. As can be seen in Table 1, PolyFlo as a single column can produce highly pure supercoiled plasmid. However, most processes for large-scale and cGMP manufacture of supercoiled plasmids require two columns (Eon-Duval and Burke, 2004; Urthaler et al., 2004). This provides a degree of assurance for the removal of contaminants, both detectable and undetectable. We therefore tested two different tandem chromatography processes: the PF-FT/PF, and the HIC/PF methods. In both processes, the crude plasmid sample is applied to the first resin under conditions where the plasmid will not bind prior to application to PolyFlo in the binding mode. For HIC chromatography, this is accomplished by adjusting the ammonium sulfate concentration to $2.1 \mathrm{M}$. For PF-FT chromatography, this is accomplished by eliminating the ion-pairing agent and increasing the ethanol concentration in the loading buffer. Under these conditions, contaminating linear and denatured forms of plasmid DNA, chromosomal DNA, as well as some endotoxin is reduced. In this context, the PF-FT mechanism is not dissimilar to HIC. Yet despite this similarity, a difference is observed between the PF-FT/PF process and the $\mathrm{HIC} / \mathrm{PF}$ process in terms of the stability and biological activity of the final product.

The implications of these results are important for the potential of supercoiled plasmids as gene-delivery vehicles. First, the process makes a difference. The same plasmid purified by four different methods resulted in different biological activity. This means the method used to purify plasmids needs to be considered very early in the development stage of a gene-based delivery vehicle product. Furthermore, the method needs to be consistent as the development process progresses through scaleup and clinical phases. Second, different plasmids may have different stabilities both dependent and independent of the method of production. As confirmed by this study, supercoiled plasmids can be unstable when stressed. Any process that can improve stability will be beneficial. Plasmids are sensitive to environmental, mechanical, and chemical stresses, each of which can induce the formation of open circular ("relaxed") or even linear forms of plasmids. When plasmids are not complexed with lipids, cations, or polymers, these latter two forms may be less biologically active than the supercoiled isomer, and while the data here support that conclusion, there is some controversy concerning this question (Lim et al., 2003). As a result, the ability to improve plasmid stability will be an important contributor to the overall success of this technology. Improvement in resistance to heat-induced stress may permit storage at higher temperatures. Resistance to serum nucleases will improve in vivo half-life. Resistance to mechanical shear enhances product integrity during transportation and resistance to chemical exposure will aid in efficacious delivery of these products to their final in vivo target. Third, the results suggest a number of factors, including residual protein, can contribute to plasmid stability and biological activity. The standard methods currently available for analyzing supercoiled plasmids need to be supplemented to include other analytical tools such as the biophysical methods presented here. 


\section{ACKNOWLEDGMENTS}

These studies were funded in part by National Institutes of Health Grant R44-GM062038-02. The authors thank Mickey Flynn and Timothy Kierstead for discussion and critical reading of the manuscript, and Dr. Kierstead for preparation of the figures. Some of these data were presented at the 8th Annual Meeting of the American Society of Gene Therapy, June 2005.

\section{REFERENCES}

AKAHATA, W., YANG, Z.Y., and NABEL, G.J. (2005). Comparative immunogenicity of human immunogenicity virus particles and corresponding polypeptides in a DNA vaccine. J. Virol. 79, 626-631.

BRAUN, C.S., JAS, G.S., CHOOSAKOONKRIANG, S., KOE, G.S., SMITH, J.G., and MIDDAUGH, C.R. (2003). The structure of DNA within cationic lipid/DNA complexes. Biophys. J. 84, 1114-1123.

CHOOSAKOONKRIANG, S., KOE, G.S., SMITH, J.G., and MIDDAUGH, C.R. (2003a). Biophysical characterization of PEI/DNA complexes. J. Pharm. Sci. 92, 1710-1722.

CHOOSAKONKRIANG, S., WIETHOFF C.M., KOE, G,S., KOE, J.G., ANCHORDOQUY, T.J., and MIDDAUGH, C.R. (2003b). An infrared spectroscopic study of the effect of hydraqtion on cationic lipid/DNA complexes. J. Pharm. Sci. 92, 115-130.

DERRICK, S.C, YANG, A. L., and MORRIS, S.L. (2004). A polyvalent DNA vaccine expressing an ESAT6-Ag85B fusion protein protects mice against a primary infection with Mycobacterium tuberculosis and boosts BCG-induced protective immunity. Vaccine 23, $780-788$.

DIOGO, M.M., QUEIROZ, J.A., MONTEIRO, G.A., MARTINS, S.A., FERREIRA, G.N., and PRAZERES, D.M. (2000). Purification of a cystic fibrosis plasmid vector for gene therapy using hydrophobic interaction chromatography. Biotechnol Bioeng. 68, 576-583.

DIOGO, M.M., QUEIROZ, J.A., and PRAZERES, D.M. (2001a). Studies on the retention of plasmid DNA and Escherichia coli nucleic acids by hydrophobic interaction chromatography. Bioseparation 10, 211-220.

DIOGO, M.M., RIBEIRO, S.C., QUEIROZ, J.A., MONTEIRO, G.A., TORDO, N., PERRIN, P., and PRAZERES, D.M. (2001b). Production, purification and analysis of an experimental DNA vaccine against rabies. J. Gene Med. 3, 577-584.

EON-DUVAL, A., and BURKE, G. (2004). Purification of pharmaceutical-grade DNA by anion-exchange chromatography in an RNase-free process. J. Chromatogr. B 804, 327-335.

EVANS, R.K., XU, Z., BOHANNON, K.E., WANG, B., BRUNER, M.W., and VOLKIN, D.B. (2000). Evaluation of degradation pathways for plasmid DNA in pharmaceutical formulations via accelerated stability studies. J. Pharm. Sci. 89, 76-87.

GEBREKIDAN, S., WOO, B.H., and DELUCA, P.P. (2000). Formulation and in vitro transfection efficiency of poly (D, L-lactide-coglycolide) microspheres containing plasmid DNA for gene delivery. AAAPS PharmSci. Tech. 1, E28-E34.

GREEN, A. (1999). Purification of supercoiled plasmids. In DNA Vaccines: Methods and Protocols. D. Lowrie and R. Whalen, eds. (Humana Press, Totowa, NJ.) p. 1-9.

GREEN, A., HUANG, J., SCOTT, M., KIERSTEAD, T., BEAUPRÉ, I., GAO, G.-P., and WILSON, J. (2002). A new scaleable method for the purification of recombinant adenovirus vectors. Hum. Gene Ther. 13, 1921-1934.

GREEN, A.P., PRIOR, G.M., HELVESTON, N., TAITTINGER B., LIU, X., and THOMPSON, J.A. (1997). Preparative purification of supercoiled plasmid DNA for therapeutic applications. BioPharmacology 10, 52-62.

HORN, N.A., MEEK, J.A., BUDAHAZI, G., and MARQUET, M.
(1995). Cancer gene therapy using plasmid DNA: Purification of DNA for human clinical trials. Hum. Gene Ther. 6, 565-573.

KNIGHT, J.D., and ADAMI, R.C. (2003). Stabilization of DNA utilizing divalent cations and alcohol. Int. J. Pharm. 264, 15-24.

KUTZLER, M., and WEINER, D. (2004). Developing DNA vaccines that call to dendritic cells. J. Clin. Invest 114, 1241-1244.

LIM, H.M., LEWIS, D.E., LEE, H.J., LIU, M., and ADHYA, S. (2003). Effect of varying the supercoiling of DNA on transcription and its regulation. Biochemistry 42, 10718-10725.

LOBO, B.A., ROGERS, S.A., CHOOSAKOONKRIANG, S., BOGDANOWICH-KNIPP, S., SMITH, J.G., KOE, G., and MIDDAUGH, C.R. (2002). Alteration of the thermal stability of plasmid DNA by cationic lipids and polymers. J. Pharm. Sci. 91, 454-466.

LOBO, B.A., VETRO, J.A. SUICH, D.M., ZUCKERMAN, R.N., and MIDDAUGH, C.R. (2003). Structure/function analysis of peptoid/lipotoid: DNA complexes. J. Pharm. Sci. 92, 1905-1918.

MANCINI-BOURGINE, M., FONTAINE, H., SCOTT-ALGARA, D., POL, S., BRECHOT, C., and MICHEL, M.L. (2004). Induction or expansion of T-cell responses by a hepatitis B DNA vaccine administered to chronic HBV carriers. Hepatology 40, 874-882.

MARSHALL, J., NIETUPSKI, J.B., LEE, E.R., SIEGEL, C.S., RAFTER, P.W., RUDGINSKY, S.A., CHANG, C.D., EASTMAN, S.J. HARRIS, D.J., SCHEULE, R.K., et al. (2000). Cationic lipid structure and formulation considerations for optimal gene transfection of the lung. J. Drug Target. 7, 453-469.

MARTIN, J.E., ENAMA, M.E., KOUP, R.A., BAILER, R.T., MOODIE, Z., ROEDERER, M., NABEL, G.J., and GRAHAM, G.S. (2005). VRC004: Safety and immunogenicity of a multiclade HIV1 DNA vaccine in healthy uninfected adults (VRC-HIVDNA009-00VP). J. Allergy Clin. Immunol. 115, 892.

MASCOLA, J.R., SAMBOR, A., BEAUDRY, K., SANTRA, S., WELCHER, B., LOUDER, M.K., VANCOTT, T.C., HYANG, Y., CHAKRABARTI, G.K., KONG, W.P., et al. (2005). Neutralizing antibodies elicited by immunization of monkeys with DNA plasmids and recombinant adenoviral vectors expressing human immunodeficiency virus type 1 proteins. J. Virol. 79, 771-779.

MIDDAUGH, C.R., EVANS, R.K., MONTGOMERY, D.L., and CASIMIRO, D.R. (1998). Analysis of plasmid DNA from a pharmaceutical perspective. J. Pharm. Sci. 87, 130-146.

MOUNT, C.N., LEE, L.K., YASIN, A., SCOTT, A., FEARN, T., and SHAMLOU, P.A. (2003). The influence of physico-chemical and process conditions on the physical stability of plasmid DNA complexes using response surface methodology. Biotech. Appl. Biochem. 37, 225-234.

PROKOP, A., KOZLOV, E., MOORE, W., and DAVIDSON, J.M. (2002). Maximizing the in vivo efficiency of gene transfer by means of nonviral polymeric gene delivery vehicles. J. Pharm. Sci. 91, $67-76$.

REXROAD, J., WIETHOFF, C.M., GREEN, A.P., KIERSTEAD, T.D., SCOTT, M.O., and MIDDAUGH, C.R. (2003). Structural stability of adenovirus type 5. J. Pharm Sci. 92, 665-678.

RIEMENSCHNEIDER, J., GARRISON, A., GEISBERT, J., JAHRLING, P., HEVEY, M., NEGLEY, D., SCHMALJOHN, A., LEE, J., HART, M.K., VANDERZANDEN, L., et al. (2003). Comparison of individual and combination DNA vaccines for B. anthracis, Ebola virus, Marburg virus and Venezuelan equine encephalitis virus. Vaccine 21, 4071-4080.

SINGH, D.K., LIU, Z., SHEFFER, D., MACKAY, G.A., SMITH, M., DHILLON, S., HEGDE, R., JIA, F., ADANY, I., and NARAYAN, O. (2005). A noninfectious simian/human immunodeficiency virus DNA vaccine that protects macaques against AIDS. J. Virol. 79, 3419-3428.

SMITH, J.M., AMARA, R.R., WYATT, L.S., ELLENBERGER, D.L., LI, B., HERNDON, J.G., PATEL, M., SHARMA, S., CHENNAREDDI, L., BUTERA, S., et al. (2005). Studies in macaques on cross-clade $\mathrm{T}$ cell responses elicited by a DNA/MVA 
AIDS vaccine, better conservation of CD8 than CD4 T cell responses. AIDS Res. Hum. Retroviruses 21, 140-144.

SMOOKER, P.M., RAINCZUK, A., KENNEDY, N., and SPITHILL, T.W. (2004). DNA vaccines and their application against parasitesPromise, limitations and potential solutions. Biotechnol. Ann. Rev. 10, 189-236.

STADLER, J., LEMMENS, R., and NYHAMMER, T. (2004). Plasmid DNA purification. J. Gene Med. 6, S54-S66.

SUMIDA, S., MCKAY, P., TRUITT, D., KISHKO, M., ARTHUR, J., SEAMAN, M., JACKSON, S., GORGONE, D., LIFTON, M., LETVIN, N., et al. (2004). Recruitment and expansion of dendritic cells in vivo potentiate the immunogenicity of plasmid DNA vaccines. J. Clin. Invest. 114, 1334-1342.

URTHALER, J., SCHLEGL, R., PODGORNIK, A., STRANCAR, AL, JUNGBAUER, A. and NECINA, R. (2004). Application of monoliths for plasmid DNA purification: Development and transfer to production. J. Chromatogr 1065, 93-106.

WANG, D., CHRISTOPHER, M.E., NAGATA, L.P., ZABIELSKI, M.A., LI, H., WONG, J.P., and SAMUEL, J. (2004). Intranasal immunization with liposome-encapsulated plasmid DNA encoding influenza virus hemagglutinin elicits mucosal, cellular and humoral immune responses. J. Clin. Virol. 31(Suppl 1), S99-S106.
WANG, R., RICHIE, T.L., BARACEROS, M.F., RAHARDJO, N., GAY, T., BANANIA, J.G., CHAROENVIT, Y., EPSTEIN, J.E., LUKE, T., FREILICH, D.A., et al. (2005). Boosting of DNA vaccine-elicited gamma interferon responses in humans by exposure to malaria parasites. Infect. Immun. 73, 2863-2872.

WIETHOFF, C.M., KOE, J.G., KOE, G.S., and MIDDAUGH, C.R. (2004). Compositional effects of cationic lipid/DNA delivery systems on transgene expression in cell culture. J. Pharm. Sci. 93, 108-123.

Address reprint requests to: Anthony P. Green, Ph.D.

Puresyn, Inc.

87 Great Valley Parkway

Malvern, PA 19355

E-mail: tony@puresyn.com

Received for publication July 6, 2005; received in revised form September 9, 2005; accepted September 12, 2005. 